Człowiek chory i umierający. Możliwości wsparcia i formy pomocy, red. J. Stala, Kraków 2014, Wydawnictwo Naukowe UPJPII, s. 217-227. http://dx.doi.org/10.15633/9788374384117.15

ks. Jerzy Kostorz

Uniwersytet Opolski

\title{
PROBLEMATYKA UMIERANIA I ŚMIERCI W KATECHEZIE MŁODZIEŻY SZKÓŁ PONADGIMNAZJALNYCH
}

W katechezie młodzieży szkół ponadgimnazjalnych istnieją pewne tematy teologiczne, które bardzo mocno łączą się z codzienną egzystencją. Przenikają one świadomość młodego człowieka, nawet jeśli unika on tych tematów lub wypiera je. Tematy egzystencjalne w katechezie w naturalny sposób wspierają refleksję teologiczną ${ }^{1}$ Wspomagają rozwój wiary. Uświadamiają młodzieży, że egzystencji ludzkiej nie można sprowadzać do życia doczesnego, do młodości i witalności. W katechezie egzystencję ludzką pojmuje się szerzej niż w świeckiej refleksji na jej temat. Po pierwsze zwraca się uwagę na nadprzyrodzony wymiar życia ludzkiego, które nie kończy się na ziemi, ale trwa wiecznie. Po drugie, okazuje się, że w katechezie należy wychodzić od doświadczeń życiowych katechizowanych i interpretować je w świetle Objawienia Bożego. Po trzecie, dostrzega się, że życie ludzkie i orędzie Boże są w relacji współzależności. Urzeczywistnienie orędzia wiary dokonuje się bowiem w konkretnym życiu ludzkim. Bez wątpienia w tej tematyce mieści się również zagadnienie umierania i śmierci. Sam problem śmierci należy do dziedziny rozważań eschatologicznych. Eschatologia jest działem teologii, który traktuje m.in. o tzw. rzeczach ostatecznych człowieka. Mówiąc o umieraniu i śmierci w katechezie mówimy zatem o tym, co kluczowe dla człowieka. Próbujemy powiązać

* KS. JERZY KOSTORZ - kapłan diecezji opolskiej, kapelan Jego Świątobliwości, doktor habilitowany teologii w zakresie katechetyki, profesor nadzwyczajny Uniwersytetu Opolskiego. Studia magisterskie w latach 1988-1994, studia doktoranckie na Katolickim Uniwersytecie Lubelskim w latach 1994-1998, rozprawa doktorska pt. Zasada wierności Bogu i człowiekowi w katechezie integralnej (1998), w latach 1998-1999- studia na Uniwersytecie Salezjańskim w Rzymie. Od 1999 roku adiunkt na Wydziale Teologicznym Uniwersytetu Opolskiego. W latach 2000-2010 - duszpasterz akademicki DA Resurrexit w Opolu. Habilitacja w 2008 roku, autor i redaktor kilku książek. Organizator wielu imprez sportowych i ewangelizacyjno-kulturalno-rozrywkowych. Wizytator nauki religii. Kapelan ludzi sportu w diecezji opolskiej. Pasjonat sportu.

1 PDK 60-62. 
problematykę teologiczną z egzystencjalną. Umieranie i śmierć towarzyszy człowiekowi od momentu narodzin. Od tej chwili każdy zbliża się do końca życia.

Można postawić tezę, że problematyka umierania i śmierci w katechezie młodzieży szkół ponadgimnazjalnych jest bardzo ważna. Dlatego pojawia się wielokrotnie w podstawie programowej i programach nauczania katechetycznego. Refleksja nad tym tematem jest zaplanowana w programie nauczania w liceum, technikum i szkole zawodowej. Problematykę umierania i śmierci należy podejmować zgodnie z podstawą programową katechezy ${ }^{2}$ i programami nauczania religii ${ }^{3}$. W tych dokumentach katechetycznych możemy znaleźć zapis celów, zadań, treści i sposobów realizacji założeń, które odnoszą się do umierania i śmieci. Poniżej przedstawione zostaną założenia programowe nauczania o umieraniu i śmierci, opisane zostaną poszczególne problemy z nimi związane. Zwrócona zostanie też uwaga na kształtowanie odpowiednich postaw wśród katechizowanych. Jednak, ażeby uniknąć niejasności i wielowymiarowości, opisane zostaną pokrótce zjawiska, będące przedmiotem niniejszych rozważań.

\section{Zjawisko umierania i śmierć}

Niejednokrotnie, zarówno w mowie potocznej, jak i w publicystyce, występują pojęcia „umierania” i „śmierci”. Uwidacznia się tu postrzeganie rzeczywistości umierania i śmierci jako bolesnych dla człowieka. Ukazywane są też różne sposoby łagodzenia bólu i lęku, jaki towarzyszy umieraniu i śmierci. Z jednej strony widoczna jest tendencja do przedłużania życia za wszelką cenę, z drugiej natomiast próbuje się oswajać człowieka ze śmiercią i pokazywać nowe sposoby łagodzenia cierpienia. Tematy te są również obecne w opracowaniach naukowych, głównie

2 Konferencja Episkopatu Polski, Podstawa programowa katechezy Kościoła katolickiego w Polsce, Kraków 2010 (Dalej skrót: PPK).

3 Komisja Wychowania Katolickiego Konferencji Episkopatu Polski, Świadek Chrystusa. Katecheza świadectwa wiary. Program nauczania religii dla liceum, nr AZ-4-01/10, w: Komisja Wychowania Katolickiego Konferencji Episkopatu Polski, Program nauczania religii rzymskokatolickiej w przedszkolach i szkołach, Kraków 2010, s. 139-169 (dalej skrót: PNR Liceum); Komisja Wychowania Katolickiego Konferencji Episkopatu Polski, Świadek Chrystusa. Katecheza świadectwa wiary. Program nauczania religii dla technikum, nr AZ-6-o1/10, w: Komisja Wychowania Katolickiego Konferencji Episkopatu Polski, Program nauczania religii rzymskokatolickiej w przedszkolach i szkołach, s. 171-206 (dalej skrót: PNR Technikum); Komisja Wychowania Katolickiego Konferencji Episkopatu Polski, Świadek Chrystusa. Katecheza świadectwa wiary. Program nauczania religii dla szkoły zawodowej, nr AZ-5-01/10, w: Komisja Wychowania Katolickiego Konferencji Episkopatu Polski, Program nauczania religii rzymskokatolickiej w przedszkolach i szkołach, s. 207-233 (dalej skrót: PNR Szkoła zawodowa). 
medycznych ${ }^{4}$. Rozwój medycyny stanowi ogromną szansę dla ciężko chorych. Może przedłużyć życie. Jednocześnie przysparza wielu różnych problemów w sytuacjach granicznych, kiedy trzeba podjąć decyzję, czy sztucznie podtrzymywać życie, czy też pozwolić człowiekowi spokojnie odejść. Często też trudno orzec czy śmierć nadeszła, czy nie ${ }^{5}$. Z kolei w teologii ukazuje się głębszy sens umierania i śmierci ${ }^{6}$. Wyraźnie zaznacza się, że człowiek nie może podejmować decyzji zarówno o życiu innych (np. dokonując aborcji, kary śmierci), jak też swoim (np. decydując się na eutanazję) $)^{7}$. Chrześcijanie wierzą, iż życie daje Bóg i tylko Bóg ma prawo je odebrać.

Biorąc pod uwagę definicje zawarte w słownikach, umieranie należy rozumieć jako proces'. Nie można zatem zredukować go do jednego momentu, zwłaszcza wtedy, gdy mamy do czynienia z powolną śmiercią ${ }^{10}$. W świetle praw biologii umieranie jest procesem naturalnym i zwykle rozciągniętym w czasie. W efekcie, proces umierania prowadzi do śmierci. To ostatnie pojęcie jest różnie określane. Zwykle przez śmierć rozumiemy przerwanie życia wszystkich narządów, tkanek i komórek ustroju. Odróżnia się zjawisko śmierci całego organizmu od śmierci fragmentów narząáów tkanek i komórek w żywym ustroju, czyli od śmierci miejscowej ${ }^{11}$. W zależności od czynników, które wywołują śmierć, wyodrębnia się też śmierć fizjologiczną i ekologiczną. Pierwsza następuje w wyniku procesów starzenia się ${ }^{12}$. Druga $\mathrm{z}$ kolei powstaje na skutek działania niekorzystnych warunków środowiskowych np. chorób, głodu, katastrof, urazów ${ }^{13}$. W tym ostatnim przypadku wyróżnia się śmierć powolną, powstałą z przyczyn biologicznych (zgon następuje w toku choroby) oraz nagłą (z powodu urazu). Istnieje również

4 Zob. np. A. Kwolek, Kontrowersje wokół medycznej definicji śmierci, „Resovia Sacra” 13 (2006), s. 137-149.

5 Zob. np. J. M. Norkowski, Kiedy umiera człowiek?: śmierć mózgowa: prawda czy fikcja?, „Zeszyty Karmelitańskie" (2006) nr 2, s. 24-33.

${ }^{6}$ Zob. Człowiek wobec bólu, cierpienia i śmierci, red. J. Stala, N. Bravena, Kraków 2013; Życie i śmierć. Wyzwania działalności charytatywnej, red. J. Stala, Tarnów 2012; Przestrzenie pracy socjalnej, red. J. Stala, Tarnów 2010.

7 Zob. np. M. Machinek, Śmierć w dyspozycji człowieka. Wybrane problemy etyczne u kresu ludzkiego życia, Olsztyn 2004.

8 Zob. np. A.F. Dziuba, Pytania wokó życia, umierania i śmierci człowieka, „Warszawskie Studia Pastoralne" 8 (2008), s. 158-177.

9 Zob. analizy na ten temat np. w: W. Wysoczański, Umieranie i śmierć: wielowymiarowość językowa, Wrocław 2012.

${ }^{10}$ M. Machinek, Śmierć w dyspozycji człowieka..., dz. cyt., s. 9-12.

${ }^{11}$ Zob. o tym np. w: T. Sahaj, Filozoficzne aspekty śmierci $w$ medycynie współczesnej, www.biotechnologia.pl/bioetyka/aktualnosci/filozoficzne-aspekty-smierci-w-medycynie-wspolczesnej-tomasz-sahaj,11931, s. $1-7$ (22.06.2014).

12 T. Sahaj, Filozoficzne aspekty śmierci w medycynie współczesnej..., dz. cyt.

13 T. Sahaj, Filozoficzne aspekty śmierci w medycynie wspótczesnej..., dz. cyt. 
taki termin jak „śmierć kliniczna”14 . Termin ten określa sytuację, w której następuje ustanie krążenia lub oddychania przy zachowanej jeszcze czynności mózgu ${ }^{15}$. Jest to krótkotrwała, trwająca około 5-8 minut odwracalna faza śmierci, z której można wyprowadzić człowieka, stosując zabiegi reanimacyjne ${ }^{16}$. W przypadku zaniechania reanimacji lub jej niepowodzenia już po kilku minutach dochodzi do śmierci mózgu. Mówimy wówczas o śmierci biologicznej, która jest ostateczna i nieodwracalna. Ten rodzaj śmierci charakteryzuje się ustaniem oznak życia, spowodowanym nieodwracalnym zburzeniem równowagi funkcjonalnej i wewnętrznej organizacji ustroju ${ }^{17}$.

Coraz częściej też, głównie w naukach medycznych i etyce, twierdzi się, że tradycyjna definicja śmierci całego organizmu, jako stanu nieodwracalnego ustania krążenia krwi, jest nieprzydatna w oddziałach intensywnej opieki medycznej, gdy krążenie krwi oraz inne funkcje organiczne podtrzymywane są sztucznie ${ }^{18}$. Poza tym tradycyjna definicja nie spełniała oczekiwań transplantologów. Definicja ta nie pozwalała pobrać narządów odpowiednio wcześnie, gdy jeszcze nadają się do przeszczepu. Dlatego poszukiwano takiej definicji śmierci, która pozwalałaby uznać organizm ludzki za martwy, mimo że część funkcji fizjologicznych (w szczególności oddychanie i krążenie krwi) mogą być i są podtrzymywane sztucznie. Wypracowano zatem nową definicję, w której pojęcie śmierci całego człowieka zastąpiono pojęciem śmierci człowieka jako całości ${ }^{19}$. Chodzi tu o zdiagnozowanie śmierci samego mózgu, którego nadrzędna, integracyjna rola wymaga bezustannego utrzymania wszystkich funkcji organizmu w harmonijnym działaniu. To śmierć mózgu jako całości, a nie śmierć całego mózgu, czyli wszystkich jego komórek stanowi podstawowe kryterium, które pozwala stwierdzić brak życia ${ }^{20}$. Mówiąc inaczej, trwałe ustanie funkcji części mózgu zwanej pniem mózgu świadczy o śmierci mózgu jako całości. Rozpoznanie śmierci mózgu, pomimo zachowania sztucznie podtrzymywanych funkcji krążenia i wentylacji, jest równoznaczne ze stwierdzeniem śmierci osobniczej ${ }^{21}$.

\footnotetext{
${ }^{14}$ www.pl.wikipedia.org/wiki/\%C5\%9Amier\%C4\%87_kliniczna, s. 1 (23.06.2014).

15 Tamże.

16 Tamże.

${ }^{17}$ B. Wójcik, Śmierć mózgu jako kryterium śmierci człowieka. Problematyka filozoficzno-etyczna, www.mp.pl/etyka/kres_zycia/show.html?id=32159, s. 1-5 (23.06.2014).

${ }^{18}$ B. Wójcik, Śmierć mózgu jako kryterium śmierci człowieka..., dz. cyt.

19 Zob. o tym np. w: K. Sobczyk, A. Janaszczyk, Kontrowersje wokół neurologicznego kryterium śmierci, „Forum Medycyny Rodzinnej” 6 (2012) nr 4, s. 182-19o.

${ }^{20}$ K. Sobczyk, A. Janaszczyk, Kontrowersje wokół neurologicznego kryterium śmierci..., dz. cyt.; Por. B. Wójcik, Mózg umiera pierwszy, „Znak” (2009) nr 6, s. 10-17.

${ }^{21}$ K. Sobczyk, A. Janaszczyk, Kontrowersje wokół neurologicznego kryterium śmierci..., dz. cyt.
} 
Dla katechezy ważne są także psychologiczne, filozoficzne i teologiczne ujęcia umierania i śmierci. Zjawiska te wiążą się wprost z życiem psychicznym człowieka. W literaturze możemy znaleźć następujące fazy procesu umierania: 1) zaprzeczenie (w przypadku chorych ma miejsce negacja diagnozy, szok, niedowierzanie); 2) gniew; 3) pertraktacje (negocjacje z Bogiem o przedłużenie życia, składanie obietnic); 4) depresja (poczucie utraty sił); 5) akceptacja śmierci (uspokojenie) ${ }^{22}$. Z kolei w myśli filozoficznej podejmowane są wysiłki przybliżenia fenomenu śmierci. Wyraźnie zaznacza się, że śmierć nie ma etapów. Próbuje się też oswajać śmierć i uśmierzać lęk z nią związany. Jednocześnie, we współczesnej filozofii, widoczne są próby wyparcia śmierci ze świadomości, co prowadzi do ukazywania śmierci jako aktu indywidualnego, któremu towarzyszy samotność, izolacja od osób bliskich i brak możliwości wpływania na jakość procesu umierania ${ }^{23}$. Filozofowie analizują też zjawisko zdecydowanej medykalizacji i depersonalizacji śmierci ${ }^{24}$. Ukazują, że dziś głównie szpital, hospicjum, dom opieki społecznej jest miejscem, w którym człowiek umiera. Lekarze są tymi, którzy walczą ze śmiercią, a w efekcie okazują się bezradni wobec śmierci ${ }^{25}$. Teologowie z kolei, opierając się na Objawieniu Bożym zawartym w Piśmie Świętym i Tradycji Kościoła, ukazują prawdę o świętości ludzkiego życia, które jest darem Stwórcy ${ }^{26}$. Przypominają, że Bóg jest Panem życia człowieka. On to decyduje kiedy człowiek umiera. Choroba, cierpienie, umieranie i śmierć są nieodłącznie wpisane w ludzką egzystencję - jako fakt powszechny, następstwo grzechu pierworodnego ${ }^{27}$. Św. Paweł wyraźnie poucza: „Przez jednego człowieka grzech wszedł na świat, a przez grzech śmierć, i w ten sposób śmierć przeszła na wszystkich ludzi, ponieważ wszyscy zgrzeszyli" $(\mathrm{Rz} 5,12)$.

W chrześcijaństwie śmierć stanowi przejście do wieczności ${ }^{28}$. Człowiek bowiem jako osoba cielesno-duchowa został powołany przez Boga do życia wiecznego $^{29}$ : „dla nieśmiertelności stworzył Bóg człowieka” (Mdr 2, 23). Warunkiem osiągnięcia życia wiecznego jest życie w sprawiedliwości przez „szukanie dobra, a nie zła" (Am 5, 14). Chrystus, jak przypominają teologowie, ukazał pełny sens ludzkiej śmierci ${ }^{30}$. Poprzez dzieło odkupienia Chrystus nadał śmierci nowy sens - ukazał,

${ }^{22}$ Zob. o tym np. w: M. Machinek, Śmierć w dyspozycji człowieka..., dz. cyt., s. 12.

${ }^{23}$ Zob. o tym np. w: W. Tyburski, Śmierć człowieka w ujęciu filozoficznym, „Udar Mózgu” 9 (2007) nr 1, s. $1-7$.

${ }^{24}$ W. Tyburski, Śmierć człowieka w ujęciu filozoficznym..., dz. cyt.

${ }^{25}$ W. Tyburski, Śmierć człowieka w ujęciu filozoficznym..., dz. cyt.

${ }^{26}$ W. Łydka, Śmierć, w: Słownik teologiczny, red. A. Zuberbier, Katowice 1998, s. 566-567.

${ }^{27}$ W. Łydka, Śmierć..., dz. cyt.

${ }^{28}$ W. Łydka, Śmierć..., dz. cyt.; Por. KKK 410, 428, 542, 625, 1007, 1221, 1392, 1524.

${ }^{29}$ W. Łydka, Śmierć..., dz. cyt.

${ }^{30}$ Zob. np. P. Góralczyk, Chrystus kluczem do tajemnicy śmierci, „Communio” 32 (2012) nr 3, s. 168-184; J. Salij, Tajemnica życia, cierpienia i śmierci, „Studia Bydgoskie” 4 (2010), s. 143-156. 
że śmierć może stać się uczestnictwem człowieka w zbawczej śmierci Chrystusa i być pełnym zwycięstwem nad grzechem oraz przejściem do domu Ojca. Magisterium Kościoła przypomina też o prawie człowieka do naturalnej śmierci ${ }^{31}$. Wyraźnie potępia eutanazję i aborcję. Zwraca przy tym uwagę na pragnienie życia wiecznego, jakie wpisane jest w serce człowieka. W konstytucji duszpasterskiej o Kościele w świecie współczesnym Gaudium et spes czytamy: „Wszelkie wysiłki techniki, choć bardzo użyteczne, nie są zdolne uśmierzyć niepokoju człowieka, bowiem przedłużenie długowieczności biologicznej nie może zaspokoić tego pragnienia dłuższego życia, które nieprzezwyciężenie tkwi w jego sercu”32.

\section{Tematyka umierania i śmierci w podstawie programowej katechezy}

W zatwierdzonym 8 marca 2010 roku podczas 351. zebrania plenarnego Konferencji Episkopatu Polski w Warszawie znowelizowanym tekście Podstawy programowej katechezy Kościoła katolickiego w Polsce dla szkół ponadgimnazjalnych ${ }^{33}$ możemy znaleźć cele, zadania i treści nauczania religii na temat umierania i śmierci. Również korelacja z edukacją szkolną oraz metodyka katechizacji w szkole sprzyja przekazywaniu wiedzy na temat umierania i śmierci oraz kształtowaniu postaw $^{34}$. Wiedza i umiejętności zaplanowane w podstawie programowej katechezy mają wyraźne nachylenie egzystencjalne. Akcentuje się w nich sferę ducha i religijny wymiar życia człowieka. Możemy tam znaleźć bezpośrednie lub pośrednie odniesienie do umierania i śmierci ${ }^{35}$. Są to tylko hasła tematyczne - słowa kluczowe. Taki bowiem charakter ma podstawa programowa katechezy.

Za ważniejsze uznać należy zarówno cele katechetyczne - wymagania ogólne, jak też zadania katechezy i nauczyciela religii oraz treści - wymagania ogólne ${ }^{36}$. W podstawie programowej katechezy wiele uwagi poświęca się analizie i interpretacji tekstów o charakterze religijnym. Uczeń ma odkrywać wartość egzystencjalną tekstów biblijnych i religijnych oraz rozwijać umiejętność wykorzystania

\footnotetext{
31 Zob. o tym w: M. Machinek, Śmierć w dyspozycji człowieka..., dz. cyt., s. 25-27; J. Stala, Osoba starsza a sens życia, w: Człowiek wobec bólu, cierpienia i śmierci, red. J. Stala, N. Bravena, Kraków 2013, s. 23-34; E. Osewska, Wartość życia i cierpienia osoby starszej w perspektywie pedagogiczno-teologicznej, w: Człowiek wobec bólu, cierpienia i śmierci, dz. cyt., s. 11-22.

${ }^{32} \mathrm{KDK} 18$.

${ }^{33}$ PPK, s. 70-102.

${ }^{34}$ Szerzej na temat nowej formuły korelacji zob. w: A. Zellma, Nowa formuła korelacji w edukacji szkolnej i jej realizacja w nauczaniu religii, „Katecheta” 55 (2011) nr 5, s. 5-16.

${ }^{35}$ PPK, s. 71-78.

${ }^{36}$ PPK, s. $71-78$.
} 
ich w dyskusji $i^{37}$. Teksty te dotyczą m.in. prawdy o Bogu - Stworzycielu oraz o Jezusie Chrystusie - Odkupicielu. Są więc ważne w katechezie na temat chrześcijańskiego rozumienia śmierci, której nowy sens nadał Chrystus poprzez dzieło odkupienia. Podobne spostrzeżenie nasuwa się, gdy czytamy o odkrywaniu powołania chrześcijańskiego oraz interpretacji doświadczenia w świetle słowa Bożego $^{38}$. Pogłębiając prawdę o Chrystusie Zmartwychwstałym i o wierze w zmartwychwstanie wszystkich ludzi, ukazuje się uczniom, że śmierć jest przejściem do życia wiecznego ${ }^{39}$. Katechizowani $\mathrm{z}$ kolei mają dostrzec związek między wiarą chrześcijan w Zmartwychwstanie Jezusa Chrystusa a powszechnym zmartwychwstaniem umarłych ${ }^{40}$.

W ramach formacji moralnej mamy szereg zadań i treści, które wiążą się z chrześcijańskim rozumieniem problematyki umierania i śmierci. Podstawa programowa katechezy dla szkół ponadgimnazjalnych zakłada „doprowadzenie do odkrycia przez ucznia godności człowieka i powołania, którym obdarzył go Bóg; prowadzenie do odkrycia własnego powołania życiowego; przygotowanie do podejmowania samodzielnych decyzji w oparciu o motywację chrześcijańską, wypływającą z faktu przyjęcia chrztu i bierzmowania; integrowanie orędzia chrześcijańskiego z ludzkim doświadczeniem codzienności; ukazanie życia chrześcijańskiego jako drogi ku doskonałości (świętości)" ${ }^{41}$. Następstwem realizacji tych zadań jest ważny dla problematyki umierania i śmierci przekaz wiedzy o osobie i jej godności oraz o wolności osoby $^{42}$. Uczeń ma odczytywać człowieczeństwo jako dar od Boga i jako zadanie. Poza tym katechizowany ma oceniać różne przypadki zachowań moralnych. Powinien też potrafić dokonać oceny rozumienia godności człowieka w różnych systemach etycznych ${ }^{43}$. Dla problematyki umierania i śmierci ważne są też problemy bioetyczne. Uczeń powinien potrafić scharakteryzować zagadnienia bioetyki takie, jak np. aborcja, eutanazja, transplantacja ${ }^{44}$. Prawidłowo podejmowane zagadnienia etyczne i bioetyczne pomagają w lepszym zrozumieniu wartości życia i naturalnej śmierci. Uświadamiają młodzieży, że każdy człowiek ma prawo do życia od poczęcia aż do naturalnej śmierci. Poza tym proponowane w podstawie programowej katechezy zagadnienia są niezbędne w zrozumieniu życia jako daru od Boga i w odkryciu powołania do życia wiecznego. Dobrze więc, że w tym dokumen-

\footnotetext{
${ }^{37}$ PPK, s. 72-73.

${ }^{38}$ PPK, s. $72-73$.

${ }^{39}$ PPK, s. $72-73$.

${ }^{40}$ PPK, s. 72-73.

${ }^{41}$ PPK, s. 75.

42 PPK, s. 75.

${ }^{43}$ PPK, s. 75.

${ }^{44}$ PPK, s. 75.
} 
cie katechetycznym mamy szereg propozycji budzenia i ugruntowania wiary oraz postępowania zgodnie z Dekalogiem. Za ważne trzeba też uznać zalecenia metodyczne, w których akcentuje się metody poszukujące ${ }^{45}$. Aktywny udział w szkolnej katechezie pozwoli młodzieży podjąć refleksję nad własnym życiem. Przyczyni się też do zdobycia umiejętności oceniania umierania i śmierci w świetle Ewangelii ${ }^{46}$. Brakuje jednak zaleceń, które bezpośrednio mogą przyczynić się do kształtowania postaw młodzieży wobec umierania i śmierci. Wychowanie uczniów do dojrzałego przeżywania procesu umierania i śmierci nie znalazło więc należytego miejsca w podstawie programowej katechezy.

\section{Tematyka umierania i śmierci w programach nauczania religii}

Propozycje zawarte w podstawie programowej katechezy szkół ponadgimnazjalnych są uszczegółowione w programach nauczania religii. Mamy tu na uwadze trzy programy: do liceum ${ }^{47}$, technikum ${ }^{48}$ i szkoły zawodowej ${ }^{49}$. Widoczne są w nich wytyczne z podstawy programowej katechezy, które rozpisano w cyklu trzy-, cztero- lub dwuletnim. W każdym z wymienionych programów nauczania religii w szkołach ponadgimnazjalnych zwraca się uwagę na wiarę w Jezusa Chrystusa. Tematyka ta występuje przede wszystkim w I klasie. Wyodrębnić można również temat roli, jaką odegrał Jezus Chrystus w historii świata i jaką odgrywa w historii każdego wierzącego człowieka ${ }^{50}$. Prawda ta jest ważna dla katechezy. Pozwala odkryć głębszy sens umierania i śmierci oraz zrozumieć powołanie człowieka do życia wiecznego. Dobrze też, że w programach nauczania religii w liceum, technikum i szkole zawodowej znajdujemy tematykę modlitwy za zmarłych ${ }^{51}$. To dodatkowo wzmacnia oddziaływanie katechetyczne. Przyczynia się do kształtowania postawy otwartej na nadprzyrodzony wymiar życia człowieka.

Treści związane z umieraniem i śmiercią są wyraźnie obecne w II klasie liceum, III klasie technikum i w I klasie szkoły zawodowej. Dotyczą one „pogłębienia rozumienia i przyjęcia prawdy o Chrystusie zmartwychwstałym i żyjącym w Kościele, przynoszącym orędzie prawdy i wolności” ${ }^{52}$. Cel ten należy osiągać,

\footnotetext{
${ }^{45}$ PPK, s. 79.

${ }^{46}$ PPK, s. 79.

${ }^{47}$ PNR Liceum, s. 139-169.

${ }^{48}$ PNR Technikum, s. 171-206.

${ }^{49}$ PNR Szkoła zawodowa, s. 207-233.

${ }^{50}$ PNR Szkoła zawodowa, s. 207-233; PNR Liceum, s. 143; PNR Technikum, s. 175.

${ }^{51}$ PNR Szkoła zawodowa, s. 214; PNR Liceum, s. 148; PNR Technikum, s. 179.

52 PNR Liceum, s. 153; PNR Technikum, s. 193; PNR Szkoła zawodowa, s. 211.
} 
omawiając zarówno dzieło odkupienia dokonane przez Chrystusa, jak też postawy człowieka wobec życia. To ostatnie zagadnienie zostaje uszczegółowione w programach nauczania religii w szkołach ponadgimnazjalnych. Wymienia się tam zagadnienia bioetyczne. Dla problematyki umierania i śmierci ważne są takie tematy, jak: aborcja i eutanazja ${ }^{53}$. W nawiązaniu do tych zagadnień proponuje się zwrócenie uwagi młodzieży na ruchy przeciwko życiu ${ }^{54}$. Obok tego rodzaju zadań w liceum i technikum zaleca się (w ramach korelacji z wiedzą o społeczeństwie) omówienie ochrony życia ludzkiego w konwencjach międzynarodowych, konstytucji i systemach prawnych ${ }^{55}$. Za ważne uznaje się też nawiązanie do postulatów obrońców życia. Na tym tle prezentuje się zagrożenia prawa do życia. Zaznacza się, że zagrożenia te są przejawem rodzenia się totalitaryzmu ${ }^{56}$. Uczniowie szkół ponadgimnazjalnych mają umieć rozpoznawać pozytywne aspekty życia, które jest darem od Boga i nikt nie ma prawa ingerować w zakończenie tego życia ${ }^{57}$. Tylko naturalny koniec życia jest godziwy, bo zgodny z prawem Bożym.

Cenna wydaje się tematyka zaplanowana w korelacji nauczania religii $\mathrm{z}$ wychowaniem do życia w rodzinie ${ }^{58}$. Wymienia się tam zagadnienie aborcji. Uczniowie mają poznać zagrożenia dla zdrowia fizycznego i psychicznego oraz wymiar medyczny, psychiczny i moralny aborcjii ${ }^{59}$. Z kolei eutanazja ukazana zostaje jako zagrożenie życia rodzinnego. Na tym tle omawia się problematykę związaną z postawą człowieka wobec cierpienia, choroby, umierania i śmierci ${ }^{60}$. Wszystkie te problemy ukazywane są $\mathrm{w}$ powiązaniu $\mathrm{z}$ życiem rodzinnym ${ }^{61}$. Ich omawianie ma kształtować wśród młodzieży ze szkół ponadgimnazjalnych chrześcijański obraz umierania i śmierci.

Warte uwagi są tematy, które dotyczą osoby i jej godności (także w różnych systemach filozoficznych), chrześcijańskiego rozumienia moralności, kryteriów czynu moralnego ${ }^{62}$. Zwykle występują one w powiązaniu z zagadnieniami bioetycznymi.

Dopełnieniem wyżej zasygnalizowanej problematyki są tematy eschatologiczne. $\mathrm{W}$ programach nauczania religii w szkołach ponadgimnazjalnych zakłada się pogłębianie prawd związanych z eschatologią. Wiele uwagi poświęca się życiu wiecznemu.

\footnotetext{
${ }^{53}$ PNR Liceum, s. 153-154; PNR Technikum, s. 193.

54 PNR Liceum, s. 153-154.

55 PNR Liceum, s. 154, 188, 194.

56 PNR Liceum, s. 154, 188, 194.

57 PNR Liceum, s. 154, 188, 194.

58 PNR Liceum, s. 154, 188, 194.

59 PNR Liceum, s. 154, 188, 194.

60 PNR Liceum, s. 154, 188, 194.

61 PNR Liceum, s. 154, 188, 194.

${ }^{62}$ PNR Liceum, s. 156.
} 
Tematykę tę wiąże się z wyznaniem wiary w zmartwychwstanie Jezusa Chrystusa i w powszechne zmartwychwstanie umarłych ${ }^{63}$. Śmierć jest ukazana jako przejście do życia wiecznego ${ }^{64}$. Świadczy to o zgodnym z nauczaniem Magisterium Kościoła ujęciu tej problematyki. Uczeń ma nabyć nie tylko wiedzę, ale i umiejętność wyjaśniania wiary w zmartwychwstanie Jezusa Chrystusa i ukazywania tej prawdy w powiązaniu z powszechnym zmartwychwstaniem umarłych ${ }^{65}$. Jednocześnie zakłada się korelację z językiem polskim. Dzięki tej czynności młodzież może odkryć w literaturze wątki tematyczne związane $z$ umieraniem i śmiercią ${ }^{66}$.

Warto zauważyć, że w programie nauczania religii dla szkół ponadgimnazjalnych zaleca się zastosowanie różnych metod dyskusyjnych i problemowych, wzbogaconych o analizę różnych tekstów (m.in. biblijnych, katechizmowych i innych źródeł informacji) ${ }^{67}$. Postulat ten odnosi się również do problematyki umierania i śmierci. Nauczanie katechetyczne na ten temat wymaga aktywnego udziału młodzieży. Warto odwoływać się do doświadczeń uczniów i podejmować dialog edukacyjny. W ten sposób możliwy będzie nie tylko przekaz wiedzy, ale także rozwój umiejętności.

\section{Zakończenie}

Zmiany społeczne i kulturowe wpłynęły na postrzeganie problematyki umierania i śmierci. Wśród młodych wzrasta koncentracja na doczesnym wymiarze życia. Dlatego przed szkolną katechezą młodzieży stoi zadanie ukazywania chrześcijańskiego wymiaru umierania i śmierci. Istotnym jest więc fakt znalezienia się tematów związanych z problematyką umierania i śmierci w podstawie programowej katechezy i programach nauczania religii dla szkół ponadgimnazjalnych. Możemy ją zauważyć w powiązaniu z tematami bioetycznymi i eschatologicznymi. Dodatkowo problematykę tę wzbogaca korelacja z edukacją szkolną. Uczniowie mogą więc uzupełniać oraz integrować wiedzę osobistą na temat umierania i śmierci.

Niezwykle pomocne są metody aktywizujące. Dzięki nim młodzież jest zachęcana do stawiania pytań egzystencjalnych i poszukiwania odpowiedzi. Punktem odniesienia w tej aktywności nie są tylko osobiste doświadczenia, ale także Ewangelia. Pobudzając młodzież do refleksji i dialogu na temat umierania i śmierci,

\footnotetext{
${ }^{63}$ PNR Liceum, s. 158, 195.

${ }^{64}$ PNR Liceum, s. 158, 195.

${ }^{65}$ PNR Liceum, s. 158, 195.

${ }^{66}$ PNR Liceum, s. 158, 195.

${ }^{67}$ PNR Liceum, s. 160, 198, 215-216.
} 
katecheta powinien uwzględnić informacje z różnych źródeł. Tylko w ten sposób można prowadzić dyskusje o istotnym znaczeniu wychowawczym.

Niewątpliwie w podstawie programowej katechezy i w programach nauczania religii dla szkół ponadgimnazjalnych zaakcentowano jedynie treści związane $\mathrm{z}$ umieraniem i śmiercią. Potraktowano je bardzo ogólnie. Nie wymieniono szczegółowych zagadnień takich, jak np. proces umierania, rodzaje śmierci, stanowisko Kościoła wobec uporczywej terapii czy innych bioetycznych zagadnień. Brakuje odniesienia do depersonalizacji, technicyzacji, desakralizacji oraz medykalizacji umierania i śmierci. Marginalnie potraktowano też kształtowanie postaw. Nie opisano żadnego zadania, które wprost dotyczyłoby kształtowania postaw młodzieży wobec umierania i śmierci. Takie podejście jest nieuzasadnione. Wymaga uzupełnienia na etapie praktyki. Sam przekaz wiedzy nie wystarczy. Szkolna katecheza ma spełniać przede wszystkim funkcje ewangelizacyjne i wychowawcze. Wymóg ten odnosi się także do problematyki umierania i śmierci. Wobec tego w przyszłości należy uzupełnić braki w dokumentach programowych szkolnej katechezy. W praktyce natomiast trzeba podejmować działania, które przyczynią się do zmiany postaw młodzieży wobec śmierci i umierania.

\section{Proponowana literatura}

Człowiek wobec bólu, cierpienia i śmierci, red. J. Stala, N. Bravena, Kraków 2013.

Dziuba A. F., Pytania wokół życia, umierania i śmierci człowieka, „Warszawskie Studia Pastoralne" 8 (2008), s. 158-177.

Góralczyk P., Chrystus kluczem do tajemnicy śmierci, „Communio” 32 (2012) nr 3, s. 168-184. Kostorz J., Eschatologiczny wymiar nauczania religii w środowisku przedszkolnym i szkolnym, „Studia teologiczno-historyczne Śląska Opolskiego” 30 (2010), s. 291-303.

Łydka W., Śmierć, w: Stownik teologiczny, red. A. Zuberbier, Katowice 1998, s. 566-567.

Machinek M., Śmierć w dyspozycji człowieka. Wybrane problemy etyczne u kresu ludzkiego życia, Olsztyn 2004.

Salij J., Tajemnica życia, cierpienia i śmierci, „Studia Bydgoskie” 4 (2010), s. 143-156.

Tyburski W., Śmierć człowieka w ujęciu filozoficznym, „Udar Mózgu” 9 (2007) nr 1, s. 1-7. Wójcik B., Mózg umiera pierwszy, „Znak” (2009) nr 6, s. 10-17.

Wysoczański W., Umieranie i śmierć: wielowymiarowość językowa, Wrocław 2012.

Życie i śmierć. Wyzwania działalności charytatywnej, red. J. Stala, Tarnów 2012. 